\title{
PENGARUH BUDAYA ORGANISASI, KEPEMIMPINAN, DAN KOMPETENSI TERHADAP KINERJA PEGAWAI
}

\section{Siti Ulyanah, Endin Syafrudin, Saddam Hussen}

Fakultas Ekonomi dan Bisnis Universitas Budi Luhur Jakarta, Indonesia

Email: syafrudinendin85@gmail.com, yanakanaya@gmail.com

saddamhasanuddin5@gmail.com

\begin{abstract}
Abstrak
Organisasi merupakan salah satu hal yang bisa menjadikan manusia menjadi manusia yang membentuk karakter pemimpin. Tujuan penelitian ini adalah untuk mengetahui dan menganalisis apakah budaya organisasi, kepemimpinan, dan kompetensi mempengaruhi kinerja pegawai di lingkungan LKPP secara parsial maupun secara simultan. Penelitian ini merupakan studi kasus yang mempelajari secara khusus dan mendalam mengenai budaya organisasi, kepemimpinan, kompetensi dan kinerja pegawai. Variabel independen penelitian adalah budaya organisasi, kepemimpinan dan kompetensi. Variabel dependen penelitian adalah kinerja pegawai. Pendekatan penelitian yang digunakan adalah pendekatan kuantitatif dengan dengan menggunakan kuisioner. Populasi penelitian ini adalah 297 pegawai di lingkungan LKPP dan menggunakan analisis regresi berganda dengan tujuan mengetahui pengaruh variabel independen budaya organisasi, kepemimpinan dan kompetensi terhadap variabel dependen yaitu kinerja pegawai. Hasil penelitian menunjukkan bahwa secara simultan budaya organisasi, kepemimpinan dan kompetensi berpengaruh signifikan terhadap kinerja pegawai. Budaya organisasi secara parsial berpengaruh signifikan terhadap kinerja pegawai, kepemimpinan tidak berpengaruh signifikan terhadap kinerja pegawai dan kompetensi berpengaruh signifikan terhadap kinerja pegawai.
\end{abstract}

Kata Kunci: budaya organisasi; kepemimpinan; kompetensi; kinerja pegawai

\section{Abstract}

Organization is one of the things that can make humans into humans who form the character of leaders. The purpose of this research was to determine and analyze whether organizational culture, leadership, and competence to employee performance in Lembaga Kebijakan Pengadaan Barang/Jasa Pemerintah (LKPP) partially or simultaneously. This research is a case study that studies specifically and in depth about organizational culture, leadership, competence and employee performance. The independent variables of this research are Organizational Culture, Leadership and Competence. The dependent variable of the study is employee performance. The research approach used is a quantitative approach by using a questionnaire. The population of this study was 297 employees in the LKPP and used multiple regression analysis with the aim of knowing the effect of the independent variables of organizational culture, leadership and competence on the dependent variable, namely employee performance. The results showed that 
simultaneously organizational culture, leadership and competence had a significant effect on employee performance. Organizational culture partially has a significant effect on employee performance, leadership has no significant effect on employee performance and competence has a significant effect on employee performance.

Keywords: organizational culture; leadership; competency; employee performance

\section{Pendahuluan}

Pengadaan Barang/Jasa Pemerintah adalah kegiatan pengadaan barang/jasa oleh Kementerian/Lembaga/Perangkat Daerah (K/L/PD) yang dibiayai oleh Anggaran Pendapatan dan Belanja Negara/Anggaran Pendapatan dan Belanja Daerah (APBN/APBD) yang prosesnya sejak identifikasi kebutuhan sampai dengan serah terima pekerjaan. Pemerintah mengeluarkan Peraturan Presiden Nomor 54 Tahun 2010 yang telah diubah menjadi Peraturan Presiden Nomor 12 Tahun 2021 tentang Pengadaan Barang/Jasa Pemerintah.

Peraturan ini dimaksudkan untuk memberikan pedoman pengaturan mengenai tata cara pengadaan barang/jasa yang sederhana, jelas dan komprehensif. Selain itu pengadaan barang/jasa diharapkan dapat meningkatkan iklim investasi yang kondusif, efisiensi belanja negara, dan percepatan pelaksanaan APBN/APBD.

Pengadaan barang/jasa pemerintah ini ditujukan untuk meningkatkan keberpihakan terhadap industri nasional dan usaha kecil yang mengutamakan penggunaan produksi dalam negeri. Pengadaan barang/jasa pemerintah memiliki aspek strategis dalam penyelenggaraan Negara dan Pemerintahan karena berfungsi membantu K/L/PD mencapai target kinerja yang menjadi tanggung jawabnya dengan penggunaan APBN/APBD yang sesuai dengan prinsip dan etika pengadaan barang/jasa pemerintah.

Dalam pelaksanaannya, pengadaan barang/jasa seringkali disorot karena transaksi anggaran yang semakin besar. Berdasarkan data tahun anggaran 2020 total belanja pengadaan barang/jasa pemerintah sebesar Rp. 1.027,1 triliun. Hasil laporan monitoring kinerja pengadaan, pada tahun 2021 pengadaan barang/jasa pemerintah mencapai $52 \%$ (lima puluh dua persen) atau Rp. 1.214,1 triliun dari anggaran belanja K/L/PD. Sehingga pengadaan barang/jasa sangat rentan terhadap kasus korupsi.

Indonesia Corruption Watch (ICW) mengatakan bahwa rentannya kasus korupsi yang ada di pengadaan barang dan jasa pada tahun 2019 sebanyak 64\% dari seluruh penindakan kasus korupsi. Kasus korupsi di sektor pengadaan barang dan jasa sangat rentan ketika proses lelang. Berdasarkan kasus korupsi yang ditangani Komisi Pemberantasan Korupsi (KPK) pada tahun 2020 hampir 70\% berkaitan dengan pengadaan barang dan jasa pemerintah.

Lembaga Kebijakan Pengadaan Barang/Jasa Pemerintah (LKPP) merupakan satusatunya lembaga pemerintah yang memiliki kewenangan untuk merumuskan perencanaan dan pengembangan strategi penentuan kebijakan serta aturan perundangan pengadaan barang/jasa pemerintah. LKPP dibentuk berdasarkan Peraturan Presiden Nomor 106 Tahun 2007 sebagaimana telah diubah terakhir melalui Peraturan Presiden Nomor 157 Tahun 2014. 
Salah satu fungsi LKPP adalah untuk merumuskan regulasi pengadaan barang/jasa pemerintah serta melakukan pembinaan dan pengembangan sistem informasi, diantaranya adalah SPSE, e-katalog, e-purchasing dan e-monev. Selain itu fungsi LKPP juga mengembangan SDM pengadaan, membina pelaku usaha dan membantu penyelesaian permasalahan pengadaan. Dalam praktiknya, LKPP berkedudukan sebagai Lembaga Pemerintah Non Kementerian (LPNK) dan bertanggung jawab langsung kepada Presiden.

Dalam menjalankan tugas dan fungsinya, LKPP di bawah koordinasi Menteri Negara Perencanaan Pembangunan Nasional/Kepala Bappenas. LKPP mempunyai tugas untuk mengembangkan dan merumuskan kebijakan pengadaan barang/jasa pemerintah. Selain itu LKPP juga bertugas menjalankan fungsi pemantauan dan evaluasi, pembinaan dan pengembangan sistem informasi serta pengawasan penyelenggaraan pengadaan barang/jasa pemerintah.

Pelaksanaan tugas dan fungsi LKPP diselaraskan dengan visi, misi, arah dan strategi kebijakan LKPP. Di samping melaksanakan program sesuai visi-misi, tujuan dan sasaran strategis, LKPP juga bertanggung jawab untuk mencapai sasaran-sasaran nasional dengan prioritas di bidang aparatur pemerintahan yang baik, peningkatan penyelenggaraan pemerintahan yang bersih, bebas korupsi, kolusi, dan nepotisme.

Permasalahan yang sering terjadi pada pengadaan barang/jasa yaitu belum optimalnya pemanfaatan sistem pengadaan seperti aplikasi Sirup (sistem informasi rencana umum pengadaan), e-tendering/e-seleksi, e-purchasing, dan e- kontrak. Permasalahan lainnya terkait dengan sumber daya manusia yaitu masih belum terpenuhinya SDM profesional yang mengelola pengadaan barang/jasa dan/atau belum terpenuhinya formasi Jabatan Fungsional Pengelola Pengadaan Barang/Jasa (JF PPBJ) serta kelembagaan pengadaan yang belum mandiri.

Dengan begitu LKPP berupaya membentuk SDM pengadaan barang/jasa yang kompeten dan profesional. Selain itu juga membentuk kelembagaan Unit Kerja Pengadaan Barang/Jasa (UKPBJ) yang unggul dan modern. Keberadaan JF PPBJ sebagai pengelola pengadaan barang/jasa pemerintah dan pemanfaatan sistem elektronik yang semakin baik, diharapkan dapat mewujudkan pengelolaan pengadaan barang/jasa menjadi lebih profesional.

Beberapa penelitian yang mendasari penelitian ini adalah penelitian yang dilakukan oleh (Ciobanu \& Ristea, 2015) yang melakukan penelitian dengan judul The Relationship Between Performance Appraisal and Civil Servants' Motivation. (Diamantidis \& Chatzoglou, 2019) melakukan penelitian dengan judul Factors Affecting Employee Performance: An Empirical Approach.

Menurut (Girniawan, Perizade, Subiyakto, \& Robbiani, 2019) melakukan penelitian bahwa kinerja pegawai dipengaruhi oleh Kepemimpinan, Budaya Organisasi, dan Kompetensi. Menurut (Jalmo Hadi Prayitno, 2020) melakukan penelitian dengan judul Pengaruh Kompetensi, Insentif dan Motivasi Terhadap Kinerja Pegawai pada Badan Narkotika Nasional Provinsi Kalimantan Tengah. 
Menurut (Danthi, 2017) melakukan penelitian dengan judul Pengaruh Gaya Kepemimpinan terhadap Lingkungan Kerja, Motivasi Kerja dan Kinerja Pegawai Negeri Sipil Pada Badan Pemberdayaan Perempuan dan Perlindungan Anak Provinsi Bali. Menurut (Hartati, 2019) dengan judul penelitian The Effect of Leadership, Organizational Culture and Work Motivation on Job Satisfaction and Job Performance among Civil Servants in Maros District Technical Working Unit.

Menurut (Friolina, Sudarsih, Endhiarto, \& Musmedi, 2017) dengan judul penelitian Do Competence, Communication, And Commitment Affect The Civil Servants Performance. Menurut (Sunya, Basalamah, Gani, \& Zakaria, 2017) melakukan penelitian dengan judul The Influence of Leadership, Competency, Motivation and Organizational Culture on Employees' Job Satisfaction and Performance in Ternate City Government.

Menurut (Rauf, Tahir, \& Yantu, 2018) dengan judul penelitian Pengaruh Pendidikan dan Pelatihan terhadap Kinerja Pegawai di Kantor Wilayah Kementerian Hukum dan Ham Gorontalo. Menurut (Rantesalu, Mus, \& Arifin, 2017) dengan judul penelitian The Effect of Competence, Motivation and Organizational Culture on Employee Performance: The Mediating Role of Organizational Commitment.

Menurut (Herawati \& Mahfudnurnajamuddin, 2018) dengan judul penelitian Pengaruh Kompetensi, Disiplin dan Iklim Organisasi Terhadap Kinerja Pegawai. Menurut (Adam \& Kamase, 2019) dengan judul The Effect Competence And Motivation To Satisfaction And Performance. Menurut (Nguyen, Yandi, \& Mahaputra, 2020) dengan judul Factors That Influence Employee Performance: Motivation, Leadership, Environment, Culture Organization, Work Achievement, Competence And Compensation.

Menurut (Sefriady \& Iskandar, 2018) dengan judul penelitian Pengaruh Pelatihan dan Disiplin Kerja Terhadap Kinerja Pegawai di Biro Organisasi dan Kepegawaian Sekretariat Jenderal Kementerian Perdagangan. Menurut (Syam'un, Mahfud Nurnajamuddin, Syahrir Mallongi \& Budiandriani., 2021) dengan judul Impact of Organizational Commitment on Civil Servants Performance: An Empirical Study of Alauddin Islamic State University of Indonesia.

Dari beberapa penelitian yang telah dilakukan bahwa kinerja pegawai dipengaruhi oleh beberapa variabel antara lain kompetensi, motivasi, pelatihan, budaya organisasi, insentif, kepemimpinan, disiplin kerja, komunikasi, komitmen, lingkungan kerja, kompensasi dan prestasi kerja. Dari variabel-variabel tersebut, peneliti melakukan penelitian tentang pengaruh budaya organisasi, kepemimpinan dan kompetensi terhadap kinerja pegawai di lingkungan LKPP.

Kinerja pegawai merupakan salah satu faktor penting dalam mencapai tujuan instansi pemerintahan maupun tujuan individu pegawai itu sendiri, tidak terkecuali bagi pegawai di lingkungan LKPP. Sebagaimana diamanatkan dalam Pasal 4 UndangUndang Nomor 5 Tahun 2014 tentang Aparatur Sipil Negara yaitu ASN sebagai profesi berlandaskan pada prinsip nilai dasar yang salah satunya meliputi mempertanggungjawabkan tindakan dan kinerjanya kepada publik. 
Kinerja pegawai LKPP secara umum menjadi sorotan dan panutan untuk Lembaga Pemerintahan. Pemerintah juga telah mengeluarkan Peraturan Nomor 46 Tahun 2011 tentang Penilaian Prestasi Kerja Pegawai Negeri Sipil dan Nomor 30 Tahun 2019 tentang Penilaian Kinerja Pegawai Negeri Sipil. Kinerja pegawai sangat diperhatikan oleh Pemerintah agar dapat menjadi bahan pembelajaran bagi instansi pemerintah lainnya.

Dalam rangka untuk menjamin adanya objektivitas dalam pembinaan Pegawai Negeri Sipil (PNS) berdasarkan pada sistem karier dan sistem prestasi kerja, pemerintah telah menerapkan sistem penilaian prestasi kerja atas pelaksanaan tugas dan kewajiban PNS sehari-hari. Hasil penilaian tersebut dituangkan dalam suatu daftar yang dibuat setiap akhir tahun yang disebut Daftar Penilaian Pelaksanaan Pekerjaan (DP3). Sesuai dengan tujuannya, maka DP3 harus dibuat seobyektif dan seteliti mungkin berdasarkan data yang tersedia.

Berdasarkan wawancara dengan Analis Kepegawaian Pertama, Muda dan Madya mengenai hasil penilaian kinerja pegawai yang diperoleh dari nilai Sasaran Kinerja Pegawai (SKP) dan perilaku kerja, bahwa hasil kinerja pegawai LKPP pada tahun 2019 dan 2020 mengalami peningkatan sangat baik. Namun masih terdapat pegawai yang mendapatkan nilai dibawah baik yaitu cukup dan bahkan buruk serta kinerja yang dihasilkan belum optimal. Hal ini diperkirakan karena adanya komunikasi yang kurang efektif antara atasan dan bawahan selama proses pelaksanaan tugas serta terdapat pegawai yang belum menunjukkan implementasi kegiatan secara baik sesuai rencana dan target yang disusun.

Kinerja pegawai sangat penting dan perlu diperhatikan karena menjadi salah satu target rencana strategis organisasi pada bidang sumber daya manusia yaitu perhitungan indeks profesionalitas Aparatur Sipil Negara (ASN) dengan kategori baik yang mencakup dimensi kualifikasi, kompetensi, kinerja dan disiplin. Dengan demikian jika kinerja pegawai tidak tercapai dengan baik maka akan berdampak pada penilaian indeks profesionalitas ASN sehingga rencana strategis organisasi tidak tercapai dan mengakibatkan kinerja organisasi kurang baik.

Penilaian kinerja yang dilakukan di LKPP masih mengacu kepada Peraturan Pemerintah Nomor 46 Tahun 2011 tentang Penilaian Prestasi Kerja PNS, yang terdiri atas unsur SKP dan perilaku kerja. Setiap PNS wajib menyusun SKP berdasarkan rencana kerja tahunan instansi yang memuat kegiatan tugas jabatan dan target yang harus dicapai dalam kurun waktu penilaian yang bersifat nyata dan dapat diukur. Penilaian SKP dilakukan dengan cara membandingkan antara realisasi kerja dan target yang meliputi aspek kuantitas, kualitas dan waktu.

Penilaian perilaku kerja dilakukan melalui pengamatan oleh pejabat penilai terhadap PNS sesuai kriteria yang ditentukan meliputi aspek orientasi pelayanan, integritas, komitmen, disiplin, kerjasama dan kepemimpinan. Penilaian prestasi kerja dilakukan dengan cara menggabungkan penilaian SKP dan perilaku kerja dengan bobot nilai unsur SKP 60\% (enam puluh persen) dan perilaku kerja 40\% (empat puluh persen). 
Tujuan penelitian ini adalah Untuk mengetahui dan menganalisis pengaruh budaya organisasi terhadap kinerja pegawai di lingkungan Lembaga Kebijakan Pengadaan Barang/Jasa Pemerintah (LKPP). Manfaat dari penelitian ini adalah Akademik, dapat memberikan referensi bagi peneliti yang ingin mengkaji permasalahan budaya organisasi, kepemimpinan dan kompetensi terhadap kinerja pegawai di lingkungan Lembaga Kebijakan Pengadaan Barang/Jasa Pemerintah (LKPP).

\section{Metode Penelitian}

Berdasarkan pendekatannya, penelitian ini adalah penelitian kuantitatif. Menurut (Emzir, 2008), pendekatan kuantitatif adalah pendekatan penelitian yang secara primer menggunakan paradigma post positivisme dalam mengembangkan ilmu pengetahuan (seperti pemikiran tentang sebab akibat, reduksi kepada variabel, hipotesis, pertanyaan spesifik, menggunakan pengukuran dan observasi, serta pengujian teori) menggunakan strategi penelitian seperti eksperimen dan survei yang memerlukan data statistik. Metode pengumpulan data merupakan langkah yang paling utama dalam penelitian, yang berguna untuk mendapatkan data yang akurat serta relevan, dan tentu saja hal ini disesuaikan dengan masalah yang akan diteliti

\section{Hasil dan Pembahasan}

1. Hasil Uji Asumsi Klasik

Uji asumsi klasik disebut juga uji linearitas, uji ini bertujuan untuk mencari tahu kelinearitasannya antara satu variabel dengan variabel yang lain sebelum menggunakan regresi linier berganda. Uji asumsi klasik dilakukan untuk mengetahui apakah model regresi yang dibuat dapat digunakan sebagai alat prediksi yang baik. Uji asumsi klasik yang akan dilakukan adalah uji normalitas, uji multikolinearitas, dan uji heteroskedastisitas

1) Hasil Uji Normalitas

Pengujian ini dilakukan untuk menguji kesalahan pengganggu dalam model regresi berdistribusi normal atau tidak. Pada penelitian ini pengujian normalitas dilakukan dengan menggunakan grafik P-Plot. Uji normalitas diperoleh dengan menggunakan program SPSS 21 for Windows. Hasil dari grafik P-Plot menggambarkan data menyebar di sekitar garis diagonal dan mengikuti arah garis. Hal ini menunjukkan bahwa penyebaran titik-titik di sekitar garis diagonal, mengindikasi model regresi memenuhi asumsi normalitas. Hasil uji normalitas tersaji pada lampiran.

2) Hasil Uji Autokorelasi

Uji autokorelasi digunakan untuk mengetahui ada atau tidaknya penyimpangan asumsi klasik autokorelasi, yaitu korelasi yang terjadi antara residual pada suatu pengamatan dengan pengamatan lain pada model regresi. Salah satu cara untuk mengetahui apakah terjadi autokorelasi atau tidak dengan menggunakan uji autokorelasi dengan uji run. Uji normalitas diperoleh dengan menggunakan program SPSS 21 for Windows. Hasil uji run test diketahui nilai 
Asymp. Sig (2-tailed) sebesar 0,879 yang lebih besar dari 0,05. Hal ini menunjukkan bahwa tidak terdapat gejala atau masalah autokorelasi. Hasil uji autokorelasi tersaji pada lampiran.

3) Hasil Uji Multikolinieritas

Uji Multikolinieritas bertujuan untuk menguji model regresi ditemukan ada atau tidaknya korelasi antara variabel bebas (independen). Ada atau tidaknya multikolinieritas dapat dilihat dari nilai tolerance dan nilai VIF. Uji multikolinieritas diperoleh dengan menggunakan program SPSS 21 for Windows. Hasil nilai tolerance pada tabel Coefficients variabel budaya organisasi adalah 0,360, variabel kepemimpinan 0,416 dan variabel kompetensi 0,668. Hasil nilai VIF variabel budaya organisasi adalah 2,778, variabel kepemimpinan 2,404 dan variabel kompetensi 1,497. Berdasarkan hasil uji multikolinieritas nilai Tolerance dari ketiga variabel independen lebih besar dari 0,05 dan nilai VIF lebih kecil dari 10,00. Hal ini menunjukkan bahwa tidak terjadi multikolinieritas antara variabel budaya organisasi, kepemimpinan dan kompetensi. Hasil uji multikolinieritas tersaji pada lampiran.

4) Hasil Uji Heteroskedastisitas

Uji heteroskedastisitas digunakan untuk mengetahui ada atau tidaknya penyimpangan asumsi klasik heteroskedastisitas yaitu adanya ketidaksamaan varian dari residual untuk semua pengamatan pada model regresi persyaratan yang harus terpenuhi dalam model regresi adalah tidak adanya gejala heteroskedastisitas. Uji heteroskedastisitas dalam penelitian ini dilakukan dengan melihat grafik scatterplot.

Uji normalitas diperoleh dengan menggunakan program SPSS 21 for Windows. Hasil dari grafik scatterplot menggambarkan titik - titik data menyebar di atas dan di bawah atau di sekitar angka 0, tidak mengumpul hanya di atas atau di bawah saja, tidak membentuk pola bergelombang melebar kemudian menyempit dan melebar kembali dan tidak berpola. Hal ini menunjukkan bahwa tidak terjadi masalah heteroskedastisitas dalam model regresi. Hasil uji heteroskedastisitas tersaji pada lampiran.

2. Hasil Koefisien Korelasi dan Determinasi

1) Analisis Hasil Koefisien Korelasi

Uji koefisien korelasi bertujuan untuk mengetahui seberapa kuat tingkat hubungan variabel independen terhadap variabel dependen dan arah korelasi yang terjadi. Uji koefisien korelasi diperoleh dengan menggunakan program SPSS 21 for Windows. Hasil dari analisis tersebut dapat dilihat pada Tabel 1 berikut: 


\section{Tabel 1}

Rekapitulasi Hasil Koefisien Korelasi

\begin{tabular}{lc}
\hline \multicolumn{1}{c}{ Nama Variabel } & Koefisien korelasi \\
\hline Budaya Organisasi & 0,567 \\
\hline Kepemimpinan & 0,387 \\
\hline Kompetensi & 0,813 \\
\hline $\mathrm{R}$ & 0,830 \\
\hline
\end{tabular}

Sumber: data primer diolah

Berdasarkan Tabel 1 dapat diperoleh sebagai berikut:

a. Uji koefisien korelasi budaya organisasi terhadap kinerja pegawai diperoleh nilai $\mathrm{R}$ koefisien korelasi untuk budaya organisasi terhadap kinerja sebesar 0,567. Hal ini menunjukkan bahwa tingkat hubungan antara variabel budaya organisasi terhadap kinerja termasuk kategori sedang.

b. Uji koefisien korelasi kepemimpinan terhadap kinerja pegawai diperoleh nilai $\mathrm{R}$ koefisien korelasi untuk kepemimpinan terhadap kinerja sebesar 0,387. Hal ini menunjukkan bahwa tingkat hubungan antara variabel kepemimpinan terhadap kinerja termasuk kategori rendah.

c. Uji koefisien korelasi kompetensi terhadap kinerja pegawai diperoleh nilai $\mathrm{R}$ koefisien korelasi untuk kompetensi terhadap kinerja sebesar 0,813. Hal ini menunjukkan bahwa tingkat hubungan antara variabel kepemimpinan terhadap kinerja termasuk kategori sangat kuat.

d. Uji koefisien korelasi budaya organisasi, kepemimpinan, dan kompetensi terhadap kinerja diperoleh nilai R koefisien korelasi untuk budaya organisasi, kepemimpinan, dan kompetensi terhadap kinerja sebesar 0,830. Hal ini menunjukkan bahwa tingkat hubungan antara variabel budaya organisasi, kepemimpinan dan kompetensi terhadap kinerja termasuk kategori sangat kuat

\section{2) Analisis Hasil Koefisien Determinasi}

Koefisien Determinasi digunakan untuk mengetahui seberapa besar pengaruh variabel bebas memiliki pengaruh terhadap variabel terikatnya. Uji koefisien korelasidiperoleh dengan menggunakan program SPSS 21 for Windows. Nilai koefisien determinasi $\left(\mathrm{R}^{2}\right)$ ditentukan dengan nilai adjusted $\mathrm{R}$ square pada Tabel 2 berikut:

Tabel 2

Hasil Koefisien Determinasi

\begin{tabular}{cc}
\hline & $\mathrm{R}^{2}$ \\
\hline Kinerja Pegawai & 0,688 \\
\hline Sumber: data primer diolah
\end{tabular}

Sumber: data primer diolah

Berdasarkan Tabel 2 diketahui bahwa nilai kontribusi variabel budaya organisasi, kepemimpinan dan kompetensi terhadap kinerja sebesar 0,688. 
Artinya kinerja pegawai dapat dijelaskan oleh variabel budaya organisasi, kepemimpinan dan kompetensi sebesar $68,8 \%$, sedangkan sisanya sebesar $31,2 \%$ dijelaskan oleh variabel lain di luar penelitian ini.

\section{Analisis Regresi Berganda}

Tujuan regresi linear berganda adalah untuk meneruskan model regresi yang paling sesuai menggambarkan faktor-faktor yang berhubungan dengan variabel terikat. Sehingga yang kita ketahui adalah pengaruh variabel budaya organisasi, kepemimpinan, kompetensi terhadap kinerja. Regresi linier diperoleh dengan menggunakan program SPSS 21 for Windows. Hasil dari analisis tersebut dapat dilihat pada Tabel 3 berikut:

\section{Tabel 3}

Rekapitulasi Hasil Analisis Regresi Linier Berganda

\begin{tabular}{llcc}
\hline \multicolumn{1}{c}{ Nama Variabel } & \multicolumn{1}{c}{ Koefisien Regresi } & $\mathbf{t}$ & Sig. t \\
\hline Budaya Organisasi & 0,190 & 3,865 & 0,000 \\
\hline Kepemimpinan & $-0,168$ & $-2,600$ & 0,010 \\
\hline Kompetensi & 0,522 & 14,061 & 0,000 \\
\hline Constanta & 9,379 & 125,154 & \\
\hline F hitung & \multicolumn{3}{c}{0,000} \\
\hline F sig & & Sur
\end{tabular}

Sumber: data primer diolah

Berdasarkan Tabel 3, diperoleh persamaan regresi sebagai berikut: $\mathrm{Y}=\alpha+\beta 1 \mathrm{X} 1$ $+\beta 2 \mathrm{X} 2+\beta 3 \mathrm{X} 3 \mathrm{Y}=9,379+0,190 \mathrm{X} 1-0,168 \mathrm{X} 2+0,522 \mathrm{X} 3$ Arti persamaan regresi linear tersebut adalah :

1.Konstanta

Nilai Konstanta 9,379, jika tanpa budaya organisasi, kepemimpinan dan kompetensi maka kinerja pegawai bernilai 9,379.

2.Budaya organisasi terhadap kinerja pegawai

Nilai koefisien regresi variabel budaya organisasi sebesar 0,190 artinya setiap kenaikan nilai koefisien budaya organisasi sebesar satu-satuan maka kinerja akan meningkat sebesar 0,190 dengan asumsi kepemimpinan dan kompetensi dianggap konstan.

3.Kepemimpinan terhadap kinerja pegawai

Nilai koefisien regresi variabel kepemimpinan sebesar -0,168 artinya setiap kenaikan nilai koefisien kepemimpinan sebesar satu-satuan maka kinerja akan menurun sebesar 0,168 dengan asumsi budaya organisasi dan kompetensi dianggap konstan.

4.Kompetensi terhadap Kinerja Pegawai

Nilai koefisien regresi variabel kompetensi sebesar 0,522 artinya setiap kenaikan nilai koefisien kompetensi sebesar satu-satuan maka kinerja akan meningkat sebesar 0,522 dengan asumsi budaya organisasi dan kepemimpinan dianggap konstan. 
Siti Ulyanah, Endin Syafrudin, Saddam Hussen

\section{Kesimpulan}

Berdasarkan hasil analisis dan pembahasan mengenai pengaruh budaya organisasi, kepemimpinan dan kompetensi terhadap kinerja pegawai di lingkungan LKPP, maka diperoleh beberapa kesimpulan penelitian sebagai berikut: (1.) Hasil pengujian deskriptif menunjukkan bahwa pada umumnya setiap indikator dan dimensi budaya organisasi, kepemimpinan dan kompetensi terhadap kinerja pegawai di lingkungan LKPP memiliki skor rata-rata yang tinggi namun demikian, (2.) Ditemukan adanya pengaruh signifikan antara budaya organisasi terhadap kinerja pegawai di lingkungan LKPP. (3.) Tidak ditemukan adanya pengaruh signifikan antara kepemimpinan terhadap kinerja pegawai di lingkungan LKPP. Hal ini berarti kepemimpinan di LKPP tidak mempengaruhi peningkatan kinerja pegawai dalam melaksanakan tugas dan pekerjaanya. (4.) Ditemukan adanya pengaruh signifikan antara kompetensi terhadap kinerja pegawai di lingkungan LKPP. (5.) Ditemukan adanya pengaruh signifikan antara budaya organisasi, kepemimpinan, dan kompetensi terhadap kinerja pegawai di lingkungan LKPP. 


\section{BIBLIOGRAFI}

Adam, Fikri, \& Kamase, Jeny. (2019). The effect competence and motivation to satisfaction and performance. International Journal of Scientific \& Technology Research, 8(03), 132-140.Google Scholar

Ciobanu, Alina, \& Ristea, Bianca. (2015). The Relationship Between Performance Appraisal And Civil Servants'motivation. Management Research \& Practice, 7(2). 5-19. Google Scholar

Danthi, Ni Made Ari. (2017). Pengaruh gaya kepemimpinan terhadap lingkungan kerja, motivasi kerja dan kinerja Pegawai Negeri Sipil pada Badan Pemberdayaan Perempuan dan Perlindungan Anak Provinsi Bali. Jurnal Ekonomi \& Bisnis JAGADITHA, 4(1), 83-94. Google Scholar

Diamantidis, Anastasios D., \& Chatzoglou, Prodromos. (2019). Factors affecting employee performance: an empirical approach. International Journal of Productivity and Performance Management. 68(1). 171-193. Google Scholar

Emzir. (2008). Metodologi Penelitian Pendidikan. Jakarta: PT Raja Grafindo Persada.

Friolina, Delvia Gita, Sudarsih, Sudarsih, Endhiarto, Tatok, \& Musmedi, Didik Pujo. (2017). Do Competence, Communication, And Commitment Affect The Civil Servants Performance? 211-215. Google Scholar

Girniawan, Eggy, Perizade, Badia, Subiyakto, Bambang Bemby, \& Robbiani, Bernadette. (2019). Pengaruh Kepemimpinan, Budaya Organisasi, Dan Kompetensi Terhadap Kinerja Pegawai Kementerian Agraria Dan Tata Ruang/Bpn Kantor Pertanahan Kota Palembang. Jurnal Manajemen Dan Bisnis Sriwijaya, 17(1), 61-78. Google Scholar

Hartati, Tati. (2019). Relationship between Leadership, Motivation, and Public Services. Budapest International Research and Critics Institute (BIRCI-Journal): Humanities and Social Sciences, 2(4), 255-261. Google Scholar

Herawati, Herawati, \& Mahfudnurnajamuddin, Mahfudnurnajamuddin. (2018). Pengaruh Kompetensi, Disiplin Dan Iklim Organisasi Terhadap Kinerja Pegawai Pada Balai Besar Pelaksanaan Jalan Nasional Vi Kementrian Pekerjaan Umum Makassar. PARADOKS: Jurnal Ilmu Ekonomi, 1(1), 46-55. Google Scholar

Jalmo Hadi Prayitno, Asriansyah S. Mawung dan Achmad Syamsudin. (2020). Pengaruh Kompetensi, Insentif dan Motivasi terhadap Kinerja Pegawai pada Badan Narkotika Nasional Provinsi Kalimantan Tengah. Journal of Environment and Management. 1(2), 91-102. Google Scholar

Nguyen, Phong Thanh, Yandi, Andri, \& Mahaputra, M. Rizky. (2020). Factors that influence employee performance: motivation, leadership, environment, culture organization, work achievement, competence and compensation (A study of human 
Siti Ulyanah, Endin Syafrudin, Saddam Hussen

resource management literature studies). Dinasti International Journal of Digital Business Management, 1(4), 645-662. Google Scholar

Rantesalu, Agustina, Mus, Abdul Rahman, \& Arifin, Zaenal. (2017). The effect of competence, motivation and organizational culture on employee performance: the mediating role of organizational commitment. Google Scholar

Rauf, Nurhayati, Tahir, Arifin, \& Yantu, Irwan. (2018). Pengaruh Pendidikan dan Pelatihan Terhadap Kinerja Pegawai Di Kantor Wilayah Kementerian Hukum dan HAM Gorontalo. JAMBURA: Jurnal Ilmiah Manajemen Dan Bisnis, 1(2), 282298. Google Scholar

Sefriady, Dea Fanny, \& Iskandar, Donant Alananto. (2018). Pengaruh Pelatihan dan Disiplin Kerja Terhadap Kinerja Pegawai di Biro Organisasi dan Kepegawaian Sekretariat Jenderal Kementerian Perdagangan. Jurnal Elektronik REKAMAN (Riset Ekonomi Bidang Manajemen Dan Akuntansi) Sekolah Tinggi Ilmu Ekonomi Galileo, 2(1), 57-68. Google Scholar

Sunya, Jusuf, Basalamah, Salim, Gani, Ahmad, \& Zakaria, Junaidin. (2017). The Influence Of Leadership, Competency, Motivation And Organizational Culture On Employees' Job Satifisfaction And Performance In Ternate City Government. International Journal of Business Management, 2 (1) 1-11. Google Scholar

Syam'un, Mahfud Nurnajamuddin, Syahrir Mallongi, Ramlawati dan, \& Budiandriani. (2021). Impact of Organizational Commitment on Civil Servants Performance: An Empirical Study of Alauddin Islamic State University of Indonesia. European Journal of Business and Management Research., 6(2).54-60.

\section{Copyright holder:}

Siti Ulyanah, Endin Syafrudin, Saddam Hussen (2021)

First publication right:

Syntax Idea

This article is licensed under:

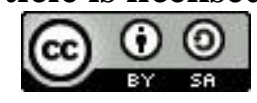

